Predrag Petrović ${ }^{1}$

Sanja Filipović ${ }^{2}$

Goran Nikolić ${ }^{3}$
JEL: E4, O24, F31

DOI:10.5937/industrija44-10977

UDC: 336.747 .4

336.748.3(497.11)

Original Scientific Paper

\title{
Testing of Currency Substitution Effect on Exchange Rate Volatility in Serbia ${ }^{4}$
}

\author{
Article history: \\ Received: 20 Martch 2016 \\ Sent for revision: 6 April 2016 \\ Received in revised form: 12 July 2016 \\ Accepted: 28 July 2016 \\ Available online: 8 October 2016
}

\begin{abstract}
Despite numerous different definitions existing in the literature, currency substitution is generally understood as a phenomenon when domestic residents prefer to use foreign currency rather than domestic currency. The main reasons for such phenomenon include high and volatile inflation, strong depreciation of national currency and high interest rate differential in favour of foreign currency. Currency substitution, as a monetary phenomenon, is widely spread in Latin American, Eastern European and some Asian countries. This paper is dedicated to the influence of currency substitution on exchange rate volatility in Serbia. The research included testing of three hypotheses: (i) currency substitution positively affects depreciation rate volatility, (ii) depreciation rate volatility has stronger responses to the past negative than to the past positive depreciation shocks, and (iii) currency substitution positively affects expected depreciation rate. The analysis was implemented for the period 2002:m1-2015:m12 (2004:m12015:m12), applying modified EGARCH-M model. Based on the obtained results, all three hypotheses have been supremely rejected regardless of the manner of quantification of currency substitution.
\end{abstract}

\footnotetext{
${ }^{1}$ Institute of Social Sciences, Belgrade

${ }^{2}$ Economics Institute, Belgrade, sanja.filipovic@ecinst.org.rs

${ }^{3}$ Institute of European Studies,Belgrade

4 The paper presents the results of a study conducted as a part of the projects: III47010, 47009, 179011, and 179014, funded by the Ministry of Education, Science and Tehnological Development, Republic of Serbia.
} 
Petrović P. et al.:Testing of Currency Substitution Effect on Exchange

Keywords: exchange rate depreciation volatility, currency substitution, EGARCH-M model, time varying conditional variance.

\title{
Testiranje uticaja valutne supstitucije na volatilnost deviznog kursa u Srbiji
}

\begin{abstract}
Apstrakt: Uprkos brojnim različitim definicijama koje egzistiraju u literaturi, valutna supstitucija se generalno shvata kao fenomen kada domaći rezidenti preferiraju upotrebu strane valute u odnosu na domaću valutu. Glavni razlozi njene pojave jesu visoka i volatilna inflacija, snažna deprecijacija nacionalne valute $i$ visok kamatni diferencijal u korist strane valute. Valutna supstitucija, kao monetarni fenomen, široko je rasprostranjena u zemljama Latinske Amerike, Istočne Evrope i nekim zemljama Azije. Ovaj rad je posvećen uticaju valutne supstitucije na volatilnost deviznog kursa u Srbiji. Tokom istraživanja testirane su tri hipoteze: (i) da valutna supstitucija pozitivno utiče na volatilnost stope deprecijacije, (ii) da volatilnost stope deprecijacije snažnije reaguje na negativne nego na pozitivne šokove $i$ (iii) da valutna supstitucija pozitivno utiče na očekivanu stopu deprecijacije. Analiza je sprovedena za period 2002:m1-2015:m12 (2004:m1-2015:m12) primenom modifikovanog EGARCH-M modela. Na osnovu dobijenih rezultata suvereno se odbacuju sve tri hipoteze bez obzira na način kvantifikovanja valutne supstitucije.
\end{abstract}

Ključne reči: volatilnost deprecijacije deviznog kursa, valutna supstitucija, EGARCH-M model, vremenski promenljiva uslovna varijansa.

\section{Introduction and literature review}

Relevant literature contains numerous definition of currency substitution, which is doubtlessly one of the main sources of confusion among economists researching this area. Despite quite considerable literature and empirical material, currency substitution commonly implies a number of different categories. For example, one of definition (Akçay, Alper \& Karasulu, 1997, p. 827) widely formulates currency substitution as shift from domestic currency towards foreign currencies caused by high and volatile inflation. Calvo and Vegh (1992, p. 4) differ between dollarization and currency substitution. Namely, according to the aforementioned authors, dollarization pertains to the state when store of value and the unit of account properties of the domestic currency are transferred to foreign currency. If the function of means of payment is transferred to foreign currency, than it is deemed to be currency substitution. Kumamoto and Kumamoto (2014, p. 698) also define currency substitution as a phenomenon when domestic residents prefer use of foreign 
currency as means of payment. Lack of a unified definition has also been confirmed by Khan and Ramirez-Rojas (1986, p. 86), emphasising the fact that currency substitution can be a wide range of various magnitudes, such as foreign exchange deposits and foreign currency notes circulating within the national borders, but also foreign exchange deposits held abroad by domestic residents. McKinnon (1985) differs between direct and indirect currency substitution, whereby he defined the direct one as presence of different currencies as means of payment, and indirect as substitutability of nonmonetary financial assets.

A significant segment of theoretical and empirical literature dealing with the phenomenon of currency substitution. Taking into consideration that currency substitution is monetary phenomenon widespread in countries with traditionally unstable economic environment and decreasing values of national currencies, there are a number of empirical studies focused on specific country case. Xaiyavong and Toyoda (2016) investigated the determinants of currency substitution in Laos, while Samreth (2011) analysed experience of currency substitution in Cambodia. Lee (2010) was focused on currency substitution in Korea, while Valev (2010) provided further evidence of currency substitution in case of Bulgaria. There are also empirical country studies for Indonesia (Kumamoto and Kumamoto, 2008), Russia (Oomes, 2003), Bolivia (Cuddington et al., 2002) and many other countries. Unlike in the previously mentioned papers, Kumamoto (2014) analysed determinants of currency substitution in eight developing and/or emerging countries (Indonesia, the Philippines, Tajikistan, the Czech Republic, Hungary, Poland, Argentina, and Peru) from different regions. This geographical spread allowed him to carry out direct cross-country comparison. This empirical research showed that the central bank could have impact on currency substitution but only to the some degree pursuing a monetary policy aimed at macroeconomic stabilization. However, more powerful policies (i.e., de-dollarization or deeuroization) should be carry out through the longer period of time for further reduction of currency substitution.

A number of research papers are dedicated to testing of its impact on exchange rate volatility. Intuitively, if a degree of currency substitution is high, demand for domestic currency depends not only on domestic nominal interest rate, but also on foreign nominal interest rate, making it more unstable, and exchange rate depreciation more volatile (Petrović, 2013).

Increased exchange rate volatility has more unfavourable impacts on macroeconomic system (Kumamoto \& Kumamoto, 2014, p. 698). Firstly, high exchange rate depreciation volatility influences increased inflation rate volatility through effects on imported goods prices. Secondly, it increases exchange rate risk, thus negatively affecting international trade and financial 
flows. Thirdly, in countries where exchange rate is used as a nominal anchor, high exchange rate depreciation volatility destabilises inflation expectations, thus compromising monetary policy goals. Link between currency substitution, inflation and welfare was analysed in a model developed by Özbilgin (2012).

Indexing of loans in foreign currencies is quite common in countries with obviously high level of currency substitution (Šoškić, 2015; Stix, 2011). The case of Serbia is especially interesting not only because of a strong intensity of the national currency but also the sterility of monetary policy in terms of strengthening confidence in the domestic currency (Milenković \& Davidović, 2013). If economic actors do not have confidence in national currency as a result of bad experience with high inflation or hyperinflation, such was the case in Serbia during the 1990s and at the beginning of 2000s, foreign currency sources of funds often present the basis for increase of credit potential of banks, which results in their need to protect themselves against currency risks by indexing their assets in foreign currency. In such circumstances, foreign currency lending plays an important role in creating of financial means of longer maturity, and this is a prerequisite for increase of investments, spending and economic growth.

Yet, high level of currency substitution which is complementary to great share of foreign currency and indexed loans, generates a range of additional problems. High exchange rate depreciation volatility influences significant increase of credit risk, which is effectuated to greater oscillations in terms of bank capital adequacy. In such ambient, there is a need to increase separation of capital reserves. Besides, negative consequences of high exchange rate depreciation volatility force central banks to intervene more intensively and more frequently at foreign currency market, which can negatively reflect on foreign currency reserves of a country.

There are numerous authors who have tried to answer the question to what extent currency substitution influences exchange rate depreciation volatility. Kumamoto and Kumamoto (2014) tested the impacts of the degree of currency substitution on nominal exchange rate volatility in seven countries (Indonesia, the Philippines, the Czech Republic, Hungary, Poland, Argentina, and Peru), applying the TARCH model. The results pertaining to the period of 2000s revealed positive impact in Indonesia, the Philippines, the Czech Republic, Hungary and Argentina. The impact was not observed in cases of Peru and Poland. In addition, asymmetric effect has been identified in Indonesia, the Czech Republic, Hungary and Poland, while in other cases there is no such effect.

Akçayet al. (1997) tested the influence of currency substitution to depreciation rate volatility in Turkey. The findings reached by applying EGARCH-M model 
for the period of 1987:01-1996:03 revealed positive and statistically significant effect. Asymmetric influence of positive and negative depreciation rate shocks was not located.

Canzoneri and Diba (1993) analysed the standpoint that capital mobility and currency substitution would result in very intensive exchange rate volatility during the period of the European monetary union establishment. The results they obtained demonstrated that with a credible commitment to the Exchange Rate Mechanism or to monetary convergence, currency substitution has very low influence to the exchange rate volatility. The main effect of currency substitution is reduction of monetary interventions frequency, which should make the Exchange Rate Mechanism more stable. Higher currency substitution can have destabilising effect if there are anticipations of a future regime switch/monetary reform or if monetary policies cease to converge.

Girton and Roper (1981) found that currency substitution generated instability in the sense that shifts in the anticipated rate of exchange rate change intensified movements in the exchange rate, which are in case of growing currency substitution unbounded.

Isaac (1989) used a conventional small open economy portfolio balance macro model so as to clarify new implications of currency substitution on exchange rate volatility. The analysis has shown that increased substitutability between foreign and domestic currency influences the exchange rate to respond more to both asset market and commodity market shocks. In addition, the extent of exchange rate overshooting and undershooting depends on the degree of currency substitution.

Kareken and Wallace (1981), using overlapping generations model, proved the exchange rate is indeterminate if domestic and foreign currencies are perfect substitutes. Besides, their findings demonstrated that even small degree of imperfect substitution is enough to specify the exchange rate, thus stressing the potential instability which can be caused by currency substitution.

Mahdavi and Kazemi (1996) also discovered that when currencies are perfect, substitutes exchange rates become indeterminate. In case of imperfect currency substitution, exchange rates could display volatility unrelated to macroeconomic fundamentals. Increase of currency substitution results in increase of exchange rate volatility, as well as in its sensitivity to change of macroeconomic fundaments.

Saatçíoğlu, Bulut and Korap (2007) researched whether the currency substitution can affect the exchange rate uncertainty for the Turkish economy. Applying the EGARCH-M model, the authors discovered a positive and 
statistically significant influence of currency substitution on exchange rate depreciation volatility, as well as that conditional variance reacts more to past positive shocks than to negative innovations of equal size.

Yinusa (2008) tested the relationship between nominal exchange rate volatility and dollarization in Nigeria by applying Granger causality test. The results obtained support a bi-directional relationship, whereby causality from dollarization to exchange rate volatility is stronger and dominates.

In this paper are presented the results of empirical research of currency substitution effect on exchange rate depreciation volatility in Serbia case. The analysis is focused on testing of three key hypotheses. The first is that currency substitution positively affects the exchange rate depreciation volatility. The second is that depreciation rate volatility has stronger (asymmetric) responses to the past negative than to the past positive depreciation shocks. The third hypothesis is that currency substitution positively affects expected monthly log depreciation rate through depreciation rate volatility.

The paper consists of five parts. Next part of the paper includes the essence of the econometric empirical methodology based on EGARCH-M model. The third part contains the most important information about data used in econometric testing. Fourth part covers empirical results of the research and, finally, the last part comprises the most significant conclusions of the analysis.

\section{Econometric methodology}

The empirical literature extensively uses different variances of conditional heteroscedastic models for exchange rates volatility modelling. High volatility of dinar/euro exchange rate depreciation provides sufficient arguments for application of such methodological framework. Since our initial hypotheses imply that presence of currency substitution affects both the mean and the time varying conditional variance of exchange rate depreciation, modified EGARCH-M model (Nelson, 1991), which in the volatility equation includes currency substitution, is the most suitable one for testing thereof. The reason for its use is contained in the fact that it is quite more flexible than other conditional heteroscedastic models because it possesses at least two key advantages (Tsay, 2010, p. 143). The first one relies on the fact that EGARCH-M model uses logged conditional variance to relax the positiveness constraint of model coefficients. The second advantage is that EGARCH-M model enables the conditional variance to respond asymmetrically to positive and negative shocks. In other words, application of this type of conditional 
heteroscedastic model enables simultaneous testing of: (a) positive influence of currency substitution on depreciation rate volatility, (b) presence of stronger depreciation rate volatility responses to the past negative than to the past positive depreciation shocks and (c) positive effect of currency substitution on expected monthly log depreciation rate. General specification of the applied EGARCH-M model has the following form:

$$
\begin{aligned}
& s_{t}=c+\sum_{i=1}^{p} \alpha_{i} s_{t-i}+\delta \ln \sigma_{t}^{2}+a_{t}, \\
& a_{t}=\sigma_{t} \varepsilon_{t}, \\
& \ln \sigma_{t}^{2}=\eta+\phi d_{t}+\sum_{i=1}^{q} \beta_{i} \ln \sigma_{t-i}^{2}+\sum_{j=1}^{p} \varphi_{j}\left|\varepsilon_{t-j}\right|+\sum_{k=1}^{m} \gamma_{k} \varepsilon_{t-k},
\end{aligned}
$$

where $s_{t}$ stands for monthly log depreciation rate, $d_{t}$ is the proxy for currency substitution and $\varepsilon_{t}$ is i.i.d. random variables with zero mean and unit variance. The hypothesis of the expected positive influence of currency substitution on time varying conditional variance of $s_{t}$ can be accepted based on statistically significant and positive coefficient $\phi$. Stronger responses in depreciation rate volatility to the past negative than to the past positive standardised shocks are confirmed by statistically significant and negative parameter $\gamma$. Finally, positive effect of currency substitution on expected monthly log depreciation rate, through depreciation rate volatility (time varying conditional variance of monthly log depreciation rate), are tested based on statistical significance and sign of currency substitution and risk premium parameters (coefficients $\phi$ and $\delta)$. Acceptance of this hypothesis requires that the aforementioned coefficients are statistically significant and positive.

\section{Data}

During the analysis, monthly data was used for two periods 2002:m12015:m12 and 2004:m1-2015:m12, depending on their availability (Table 1). Monthly log depreciation rate series was obtained by differencing logarithm of nominal bilateral exchange rate between RSD and euro. Since literature does not contain generally accepted and unified definition of currency substitution, this variable was quantified in five ways. The first indicator (d1) was calculated as ratio of foreign exchange deposits to money supply M3. The second variable $(d 2)$ is ratio of foreign exchange deposits to domestic currency deposits. The third measure $(d 3)$ is ratio of foreign exchange deposits to 
money supply M2. The fourth $(d 4)$ is ratio of foreign exchange savings to total savings of households. Finally, the fifth variable (d5) is ratio of foreign exchange savings to domestic currency savings of households. All data was taken from the official web site of the National Bank of Serbia. Models incorporating the first three indicators of currency substitution were estimated for the period of $2002: \mathrm{m} 1-2015: \mathrm{m} 12$, while the remaining two models are based on sample for 2004:m1-2015:m12.

Table 1 Variables Used in the Empirical Research

\begin{tabular}{|c|c|c|}
\hline Variable & Label & Description \\
\hline $\begin{array}{l}\text { Log of exchange rate } \\
\text { depreciation }\end{array}$ & $s$ & Average of period \\
\hline $\begin{array}{l}\text { Degree of currency } \\
\text { substitution }\end{array}$ & $d 1$ & $\begin{array}{l}\text { Ratio of foreign exchange } \\
\text { deposits to money supply } \\
\text { M3 (average of period) }\end{array}$ \\
\hline $\begin{array}{l}\text { Degree of currency } \\
\text { substitution }\end{array}$ & $d 2$ & $\begin{array}{l}\text { Ratio of foreign exchange } \\
\text { deposits to domestic } \\
\text { currency deposits (average } \\
\text { of period) }\end{array}$ \\
\hline $\begin{array}{l}\text { Degree of currency } \\
\text { substitution }\end{array}$ & $d 3$ & $\begin{array}{l}\text { Ratio of foreign exchange } \\
\text { deposits to money supply } \\
\text { M2 (average of period) }\end{array}$ \\
\hline $\begin{array}{l}\text { Degree of currency } \\
\text { substitution }\end{array}$ & $d 4$ & $\begin{array}{c}\text { Ratio of foreign exchange } \\
\text { savings to total savings of } \\
\text { households (average of } \\
\text { period) }\end{array}$ \\
\hline $\begin{array}{l}\text { Degree of currency } \\
\text { substitution }\end{array}$ & $d 5$ & $\begin{array}{c}\text { Ratio of foreign exchange } \\
\text { savings to domestic } \\
\text { currency savings of } \\
\text { households (average of } \\
\text { period) }\end{array}$ \\
\hline
\end{tabular}

Source: Authors

\section{Empirical results and discussion}

Modelling of time varying conditional variance of monthly log depreciation rate applying the EGARCH-M conditional heteroscedastic model, requires stationary residuals. This condition implies that monthly log depreciation rate 
Petrović P. et al.:Testing of Currency Substitution Effect on Exchange

is a stationary series, under univariate time series modelling, which is confirmed by the results of the unit root tests (Table 2).

Table 2 Unit Root Tests Results

\begin{tabular}{ccccccc}
\hline \hline Variable/test & \multirow{2}{*}{$\mathrm{dc}$} & $\mathrm{k}$ & $\mathrm{ADF}$ & $\mathrm{DF}-\mathrm{GLS}$ & $\mathrm{PP}$ & $\mathrm{K} P S S$ \\
\hline \multirow{2}{*}{$s$} & \multirow{2}{*}{$\mathrm{c}+$ trend } & 7 & -4.533 & -4.399 & -8.689 & 0.042 \\
& & & $(-3.438)$ & $(-2.971)$ & $(-3.437)$ & $(0.146)$ \\
\hline
\end{tabular}

Note: dc represents deterministic components in ADF, DF-GLS, PP and KPSS tests, $\mathbf{k}$ the number of lags which aim to eliminate autocorrelation in residuals in ADF test regression equation. Critical values at $5 \%$ significance level are shown in the parentheses. The testing was conducted using software package EViews 5.1.

Source: Authors

ARMA modelling of this series yielded the following auto-regression model:

$$
\begin{gathered}
s_{t}=0.004+0.388 s_{t-1}-0.180 s_{t-5}+a_{t} . \\
(0.001) \quad(0.072) \quad(0.072)
\end{gathered}
$$

Respective values of Ljung-Box statistics for residual series and squared residual series $\left[Q(20)=21.930(0.235)\right.$ and $\left.Q^{2}(20)=58.803(0.000)\right]$ indicate absence of serial correlation and presence of ARCH effect. Also, Lagrange multiplier test of Engle $[F=10.505$ (0.001)] reveals a strong $\mathrm{ARCH}(1)$ structure.

Estimates of the parameters under the EGARCH-M specification have been presented in Table 3 . The first and very significant fact observed is a convincing statistical insignificance of currency substitution proxies in all five models in which they appear, regardless of the manner of their quantification. Eliminating of currency substitution from the equation results in estimation of the sixth model in which the asymmetric component $\left(\varepsilon_{t-1}\right)$ and risk premium variable $\left(I n \sigma_{t}^{2}\right)$ are statistically insignificant. If risk premium variable is excluded, the asymmetric component remains convincingly insignificant (model 7). Reverse order of variables elimination implies estimation of model 8 , in which the risk premium variable is insignificant at $5 \%$ significance level (but at the border of statistical significance at $10 \%$ significance level). Exclusion thereof from the equation resulted in the final model (model 9) in which all variables are statistically significant at $1 \%$ significance level. For model checking, the Ljung-Box test for the standardized residual process and squared standardized residual process, as well as ARCHLM test $\left[Q(20)=15.729(0.675), Q^{2}(20)=8.0076(0.987)\right.$ and $\left.F=0.336943(0.996594)\right]$ 
showed that there is no serial correlation or conditional heteroscedasticity in the standardised residuals of the fitted model 9, which means prior AR(1)$\mathrm{EGARCH}(1,1)-\mathrm{M}$ model is adequate.

The presented econometric results lead to several key findings. The first refers to the fact that there is no proof that degree of currency substitution influences volatility of monthly log depreciation rate in Serbia, regardless of the method of its quantification. The second finding is that there is no asymmetric effect, which means that positive and negative shocks of the same magnitude have the same effect on the volatility of monthly log depreciation rate. Finally, the results demonstrate that there are no reliable proofs about statistical significance of risk premium variable. Comparing of these findings to equivalent researches is not possible unfortunately, because to the authors' knowledge, such analyses have not been conducted for Serbia so far. Comparing to researches which used similar methodological framework, conducted for other countries, such as Akçay et al. (1997) and Kumamoto and Kumamoto (2014), revealed only partial compatibility. Namely, compatibility with Akçay et al. (1997) exists in terms that no asymmetric influence had been revealed, but findings are different when it comes to the currency substitution effect. Partial compatibility with Kumamoto and Kumamoto (2014) is reflected in the fact that authors of this research also had not succeeded in estimating the significant influence of currency substitution in Peru and Poland, nor had it proved asymmetric effect in Argentina, Peru and Philippines. 


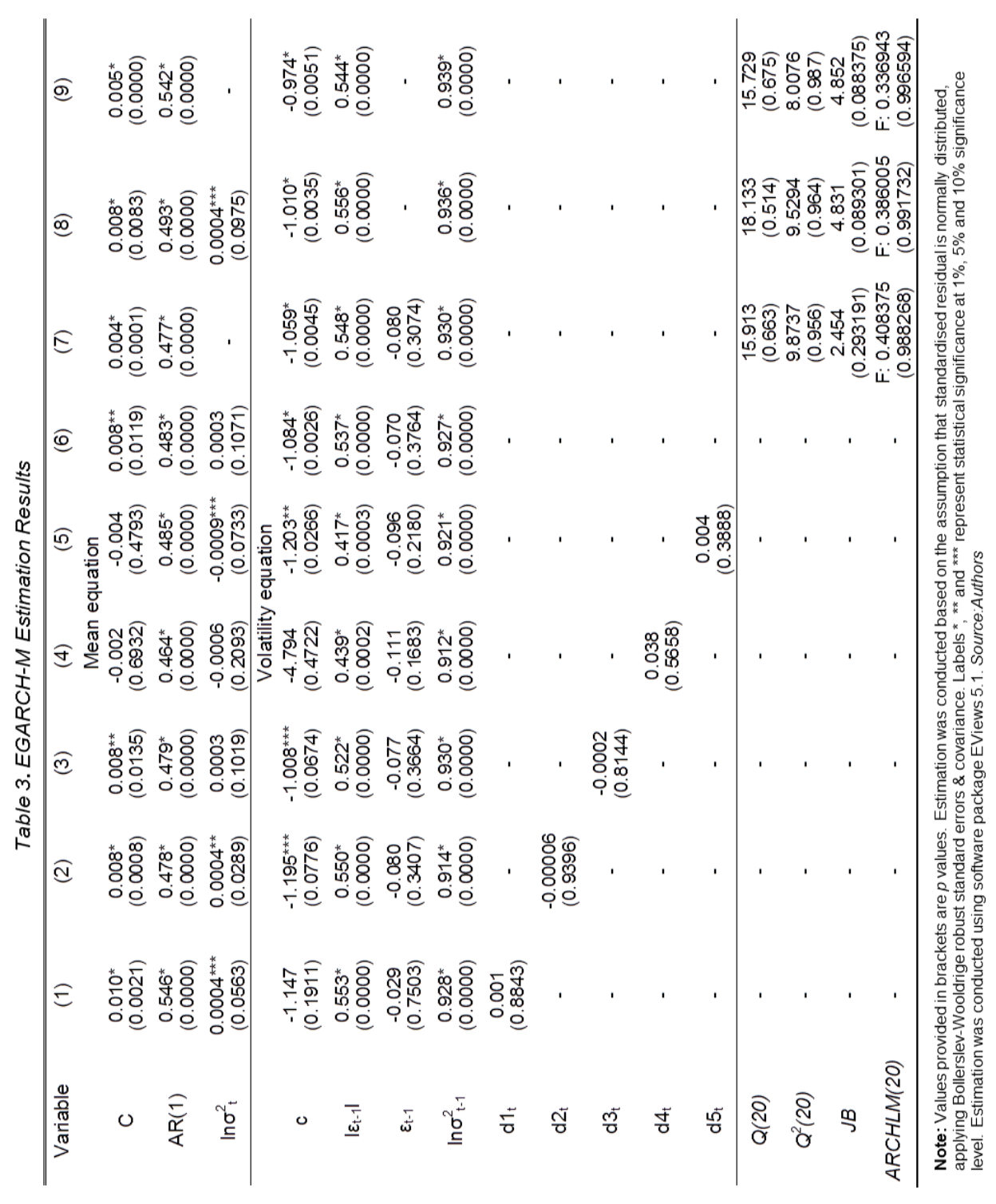




\section{Conclusion}

In this paper, the following hypotheses were tested: (a) currency substitution positively affects depreciation rate volatility, (b) depreciation rate volatility has stronger responses to the past negative than to the past positive depreciation shocks and (c) currency substitution positively affects the expected monthly log depreciation rate through depreciation rate volatility. Based on the results obtained by applying the modified EGARCH-M model, all three hypotheses have been rejected with high degree of reliability. The first and the third one are rejected due to the fact that currency substitution is convincingly insignificant variable in all estimated models, regardless of the manner of its quantification. The second hypothesis was supremely rejected since the asymmetric component was statistically insignificant in all equations.

The main importance of this analysis is that according to authors' knowledge, it is the only research of this type conducted for Serbia. Further analysis, depending on data availability, could be focused on checking of the obtained results on series with daily frequency. Despite numerous risks and lacks always brought by high degree of currency substitution, due to which the National Bank of Serbia at the beginning of 2010 initiated the so-called strategy of Serbian financial system dinarisation, we would like to stress that at present there are not proofs about statistically significant effects of currency substitution on exchange rate depreciation volatility.

\section{References}

Akçay, O.C., Alper, C.E., \& Karasulu, M. (1997). Currency substitution and exchange rate instability: The Turkish case. European Economic Review, 41, 827-835.

Calvo, G.A., \& Vegh, C.A. (1992). Currency substitution in developing countries: An introduction. Revista de Análisis Económico, 7(1), 3-27.

Canzoneri, M.B., \& Diba, B.T. (1993). Currency substitution and exchange rate volatility in the European Community. Journal of International Economics, 35(34), 351-365.

Cuddington, J., Garcia, R.M., \& Westbrook, D. (2002). A micro-foundations model of dollarization with network externalities and portfolio choice: The case of Bolivia. Retrieved from http://inside.mines.edu/ jcudding/papers/Currency_Substitution/CGW_CS.pdf

Girton, L., \& Roper, D. (1981). Theory and implications of currency substitution. Journal of Money, Credit, and Banking, 13(1), 12-30.

Isaac, A.G. (1989). Exchange rate volatility and currency substitution. Journal of International Money and Finance, 8(2), 277-284.

Kareken, J., \& Wallace, N. (1981). On the indeterminacy of equilibrium exchange rates. Quarterly Journal of Economics, 96(2), 207-222. 
Khan, M.S., \& Ramirez-Rojas, C.L. (1986). Currency substitution and government revenue from inflation. Análisis Económico, 1(1), 79-88.

Kumamoto, H., \& Kumamoto, M. (2008). Currency substitution, network externalities and hysteresis effects. Journal of Commerce, Economics and Economic History, 77(1), 1-13.

Kumamoto, H., \& Kumamoto, M. (2014). Does currency substitution affect exchange rate volatility?. International Journal of Economics and Financial Issues, 4(4), 698-704.

Kumamoto, H. (2014). Recent Experiences with Currency Substitution. International Journal of Financial Research, 5(4), Retrieved from http://www.sciedu.ca/journal/index.php/ijfr/article/view/5406/3197

Mahdavi, M., \& Kazemi, H.B. (1996). Indeterminacy and volatility of exchange rates under imperfect currency substitution. Economic Inquiry, 34(1), 168-181.

Mckinnon, R.I. (1985). Two concepts of international currency substitution. In M.D. Connoly \& J. McDermott (Eds.), The economics of the Caribbean Basin. (pp. 101-113). New York: Praeger.

Milenković, I., \& Davidović, M. (2013). Determinants of Currency Substitution/Dollarization - The Case of the Republic of Serbia. Journal of Central Banking Theory and Practice, 139-155.

Lee, S.R. (2010). Is There Currency Substitution in Korea?. International Area Studies Review, 13, 243-249.

Nelson, D.B. (1991). Conditional heteroskedasticity in asset returns: A new approach. Econometrica, 59(2), 347-370.

Oomes, N. (2003). Network externalities and dollarization hysteries: The case of Russia. IMF Working paper, Retrieved from https://www.imf.org/external/pubs/ft/wp/2003/wp0396.pdf

Özbilgin, H.M. (2012). Currency substitution, inflation, and welfare. Journal of Development Economics, 99(2), 358-369.

Petrović, P. (2013). Testing of real exchange rate: Real interest rate differential relationship in Serbia: EMU case. Industrija, 41(4), 111-125.

Saatçíoğlu, C., Bulut, C., \& Korap, L. (2007). Does currency substitution affect exchange rate uncertainty?, The case of Turkey. MPRA Paper, 20319,

Samreth, S. (2011). An empirical study on the hysteresis of currency substitution in Cambodia. Journal of Asian Economics, 22(6), 518-527.

Stix, H. (2011). Euroization: What factors drive its persistence?, Household data evidence for Croatia, Slovenia and Slovakia. Applied Economics, 43(21), 26892704.

Šoškić, D. (2015). EU banking union: Lessons for non-eurozone transition countries. Industrija, 43(2), 164-181.

Tsay, R.S. (2010). Analysis of Financial Time Series. Chicago, IL: John Wiley \& Sons..

Yinusa, D.O. (2008). Between dollarization and exchange rate volatility: Nigeria's portfolio diversification option. Journal of Policy Modeling, 30(5), 811-826.

Valev, T.N. (2010). The hysteresis of currency substitution: Currency risk vs. network externalities. Journal of International Money and Finance, 29(2), 224-235.

Xaiyavong, I., \& Toyoda, T. (2016). Currency Substitution in Laos. Asian Economic Journal, 30(1),

67-89. 
